\title{
Philanthrocapitalism: Promoting Global Health but Failing Planetary Health
}

\author{
Colin D Butler 1,2,3 \\ 1 National Centre for Epidemiology and Population Health, Australian National University, Canberra 0200, \\ Australia; colin.butler1955@gmail.com \\ 2 Health Research Institute, University of Canberra, Bruce ACT 2617, Australia \\ 3 College of Arts, Humanities \& Social Sciences, Flinders University, Bedford Park, SA 5042, Australia
}

Received: 30 January 2019; Accepted: 19 March 2019; Published: 23 March 2019

\begin{abstract}
Focusing on the Bill and Melinda Gates Foundation (BMGF) as a case study, this paper explores the relationship between philanthrocapitalism, economic history, and global and planetary health. The Wellcome Trust is also briefly discussed, chiefly in the context of planetary health. The paper argues that in the last 45 years there has been an increased preference for market-based approaches, often called neoliberalism, particularly in the U.S. and its allies. This has generated greater inequality in many high-income settings and weakened the norm of taxation. This has provided a setting in which philanthrocapitalism has flourished, including the BMGF. The latter has in turn become an important actor for global health, partially balancing the adverse consequences of neoliberalism. Planetary health is here defined as the interaction between global health and global environmental change, including to the climate and other elements of the Earth System. Although the Wellcome Trust has recently made funds available for ecological health research, it continues to invest in fossil fuels. The Gates Foundation provide no or minimal grants for ecological or planetary health but appear to have recently substantially divested from fossil fuels, for unclear reasons. The paper concludes that these large philanthrocapitalist organizations partly compensate for the decline in attention to global health driven by market-preferring solutions, but remain insufficiently proactive in the face of the great dangers associated with declining planetary health.
\end{abstract}

Keywords: Bill and Melinda Gates Foundation; capitalism; climate change; disinvestment; economic history; effective altruism; global health; health systems; malaria; metrics; neoliberalism; philanthrocapitalism; philanthropy, planetary health; vaccines; Wellcome Trust

\section{Introduction}

This introduction defines and discusses the three key terms most relevant to this article; philanthrocapitalism, global health, and planetary health. Part two reviews economic history, seeking to position the arising of philanthrocapitalism in the wider context of national and global inequality. The third section describes several characteristics of the Bill and Melinda Gates Foundation (BMGF) relevant to global and planetary health. These include its alleged authoritarianism, its preference for technological rather than social interventions, its support for vertical (disease-focused) approaches rather than the strengthening of national, "horizontal" health systems and its fondness for metrics. Part four focuses on climate change, carbon divestment, and the role and responsibility of leadership for planetary health that philanthrocapitalists should demonstrate. The conclusion argues that the BGMF and other philanthrocapitalists have brought the trajectory for global health closer to the vision that seemed possible to international health activists in the 1970s but which faded in following decades. However, philanthrocapitalism is in general insufficiently aware of the great dangers associated with declining planetary health. 


\subsection{Examples of Philanthrocapitalism}

The term philanthrocapitalism was coined only in 2006, but its existence is far older [1]. It is here defined as the use of large sums of money and associated political and economic power, accumulated in capitalist economies, for philanthropic purposes. The word philanthropy is derived from philo (Greek for love) and anthro (Greek for human). Leading examples of philanthrocapitalist organizations include the BMGF, the Wellcome Trust, the Open Foundations, and the United Nations (UN) Foundation (see Table 1).

Table 1. Some of the most prominent examples of philanthrocapitalism in the English-speaking world. Key: \# My enquiry was unanswered.

\begin{tabular}{|c|c|c|c|c|c|c|}
\hline Name & Founder(s) & Founded & Website & $\begin{array}{l}\text { Assets (a)/ } \\
\text { Endowment } \\
\text { (e) (US\$ bn) }\end{array}$ & $\begin{array}{c}\text { Annual } \\
\text { Budget US\$ } \\
\text { (bn) }\end{array}$ & $\begin{array}{c}\text { Carbon } \\
\text { Investment } \\
\text { Policy }\end{array}$ \\
\hline $\begin{array}{c}\text { Bill and } \\
\text { Melinda Gates } \\
\text { Foundation }\end{array}$ & $\begin{array}{c}\text { Bill and } \\
\text { Melinda } \\
\text { Gates }\end{array}$ & 2000 & https://www.gatesfoundation.org/ & 46 (a) & 4.7 & $\begin{array}{l}\text { largely or } \\
\text { fully } \\
\text { divested }\end{array}$ \\
\hline $\begin{array}{l}\text { Wellcome } \\
\text { Trust }\end{array}$ & $\begin{array}{c}\text { Henry } \\
\text { Wellcome }\end{array}$ & 1936 & https://wellcome.ac.uk/ & 27 (a) & $1.4(2017)$ & invest \\
\hline $\begin{array}{l}\text { The Open } \\
\text { Foundations }\end{array}$ & $\begin{array}{l}\text { George } \\
\text { Soros }\end{array}$ & 1979 & $\begin{array}{c}\text { https://www.opensocietyfoundatio } \\
\text { ns.org/about }\end{array}$ & $18(\mathrm{e})$ & & unsure \\
\hline $\begin{array}{l}\text { Leverhulme } \\
\text { Trust }\end{array}$ & $\begin{array}{l}\text { William } \\
\text { Lever }\end{array}$ & 1925 & https://www.leverhulme.ac.uk/ & $4.2(a)$ & 0.1 (2017) & unsure \\
\hline $\begin{array}{l}\text { Rockefeller } \\
\text { Foundation }\end{array}$ & $\begin{array}{c}\text { John D } \\
\text { Rockefeller }\end{array}$ & 1913 & $\begin{array}{l}\text { https://www.rockefellerfoundation. } \\
\text { org/about-us/our-history/ }\end{array}$ & 4.1 (a) (2016) & & $\begin{array}{c}\text { fully } \\
\text { divested }\end{array}$ \\
\hline $\begin{array}{c}\text { The UN } \\
\text { Foundation }\end{array}$ & Ted Turner & 1998 & https://unfoundation.org/ & 2 (a) & 0.115 & unsure \# \\
\hline
\end{tabular}

\subsection{Global and Planetary Health}

The terms global health and planetary health have a long and intertwined history [2-4]. Global health is viewed, by most, as the contemporary name for what was originally called tropical medicine and then international health. Some scholars, however, have long argued that global health also includes a focus on issues that directly or indirectly affect health but which transcend national boundaries, including anthropogenic climate change and antibiotic resistance [5]. In this conceptualization, global health (unlike international health) embraces some high-income populations in the global North, i.e., developed countries, and overlaps with planetary health.

The term "planetary health" is at least 40 years old [6], but has recently attained prominence due to the support of the Lancet, the Rockefeller Foundation, and the subsequent formation of the Planetary Health Alliance. A key document of its recent formulation is a self-described manifesto, published in The Lancet in 2014, led by Richard Horton, the journal's long-standing editor [7]. This article (see Box 1) stresses the importance of social justice, and explicitly warns that civilization is at risk, not only from climate change, but from a constellation of other factors, including inequality [8]. It also explicitly links what it perceives as a downward spiral to neoliberalism [9].

Box 1. Text about neoliberalism in "From public to planetary health: a manifesto" [7].

The idea of unconstrained progress is a dangerous human illusion: success brings new and potentially even more dangerous threats. Our tolerance of neoliberalism and transnational forces dedicated to ends far removed from the needs of the vast majority of people, and especially the most deprived and vulnerable, is only deepening the crisis we face [7].

Some critics have argued that this encouraging acknowledgement of inequality and global social injustice remains largely stillborn (see Table 2) [2,6]. A recent paper, written by the inaugural director of the Planetary Health Alliance describes the rift between those who have largely caused the environmental crisis and those most vulnerable to it as deeply unfair, and calls its solution "a moral 
imperative" [10]. However, the article is vague on practical ways to escape our planetary crisis and does not otherwise analyze or criticize the global economic system.

Table 2. Prominent themes of ecohealth, international health, global health, One Health, planetary health (two flavors) and public health. Key * most common definition; \# less common definition; ^ not just total size but growth rate as a determinant of health outcomes; PHA = Planetary Health Alliance; $\mathrm{iV}=$ inVIVO; dark green = strong, light green = moderate; orange = weak.

\begin{tabular}{|c|c|c|c|c|c|c|c|}
\hline $\begin{array}{c}\text { Health } \\
\text { Discipline }\end{array}$ & Multi-Disciplinary & $\begin{array}{c}\text { Focus on } \\
\text { Poor }\end{array}$ & $\begin{array}{l}\text { Global } \\
\text { Structural } \\
\text { Power }\end{array}$ & $\begin{array}{l}\text { Eco-Climatic } \\
\text { Factors }\end{array}$ & $\begin{array}{l}\text { Infectious } \\
\text { Diseases }\end{array}$ & $\begin{array}{l}\text { Demographic } \\
\text { Factors }\end{array}$ & Conflict \\
\hline \multicolumn{8}{|l|}{ Ecohealth } \\
\hline \multicolumn{8}{|l|}{ Global * $^{*}$} \\
\hline \multicolumn{8}{|l|}{ Global \# } \\
\hline \multicolumn{8}{|l|}{ International } \\
\hline \multicolumn{8}{|l|}{ One Health } \\
\hline \multicolumn{8}{|l|}{ Planetary (PHA) } \\
\hline \multicolumn{8}{|l|}{ Planetary (iV) } \\
\hline Public & & & & & & & \\
\hline
\end{tabular}

There is an alternative planetary health movement, associated with the Canmore Declaration [3], the inVivo Planetary Health Network and this journal. It is premature to characterize this movement, but a candidate distinction may be greater optimism [6,11]. However, at least one recent paper in this tradition recognizes that the point of successful transition, if there is to be one, between the past (a time of little appreciation of limits) and the future (where limits are apparent) will be a period of maximal conflict and tension [11]. This explicit recognition of limits and the risk of conflict is, as yet, rare in either of the contemporary planetary health fields [4].

Both versions of planetary health have a strong eco-climatic focus, as do the disciplines ecohealth [4] and some forms of One Health [12]. There is agreement that global health shares with public health and international health a priority on population-based and preventive foci, and a concentration on poorer, vulnerable, and underserved populations. Table 2 compares and contrasts some of the key similarities and differences between global health, planetary health, and some of their companion disciplines that have evolved in the long struggle to improve world health. This table is based on my involvement with these issues for over three decades (see Appendix A).

\subsection{The Peril of Failing Planetary Health}

As difficult as global health problems are, they are potentially dwarfed by the suite of issues embraced by the term planetary health. Ecosystem change, climate change, and the social interactions, including conflict and migration, from the human encounter with limits to growth present formidable problems to sustainable population health $[4,11]$. Realization of these challenges is inhibited, including by "scientific reticence" [13]. A disconnect exists between the level of risk and the declining appreciation of it by most funders, researchers, reviewers and policy-makers who remain insufficiently aware of the severity and intractability of the risks posed [8]. A supplementary appendix to the first main paper on planetary health argues "wealth can insulate powerful elites from the perceived risk of future threats, but if civilizational collapse is imminent, the wealth of a few can mask the gravity of threats to all and weaken incentives to act until it is too late" [14]. This warning is not hyperbole.

\section{Inequality, Revolts and Epidemics: The Seedbed for Health Philanthrocapitalism}

This section seeks to position the evolution of philanthrocapitalism in the context of economic history, evolution, and complexity theory. Humans, like other primates and many other social animals, are a hierarchical species, but the scale of tolerable inequality is not infinite. Excessive inequality, where visible, leads to resentment, and, at times organized revolt [15]. To reduce this risk, elites both disguise their wealth and, at times, redistribute part of it. In the Roman Empire, elites, sometimes 
incredibly wealthy, had informal obligations to reduce hardship of the masses, if they were affected by crisis [16]. Similar obligations also existed for Indian rulers.

\subsection{Saving the British Class System}

In the early 19th century, there was anxiety among the British ruling class that revolution would cross the English Channel, following the 1789 French Revolution. Unrest and dissent in Britain did occur, yet extreme, state-supported domestic violence to quell protest gradually abated, while the 1832 Repeal Act ceded some power to workers, although the reform of the British Poor Law in 1834 halved national spending on welfare [17].

The easing of suppression was combined with growing economic opportunities to a rising proportion of the British population, soothing unrest in Britain, apart from in Ireland. Opportunities afforded by the industrial revolution and by the enormous, still expanding empire, itself founded on coercion and violent state power $[18,19]$, contributed to wealth that led to the emergence of a large British middle class, widespread literacy, sewage systems in the major towns and even to garden cities [20]. After an initial dip in the 1830s and 1840s, probably worsened by the temporary cessation of organized smallpox vaccinations in Glasgow and perhaps elsewhere [17], British life expectancy improved through the 19th century [20]. This was not only due to economic "take-off" [21] based on ingenuity as well as distant pillage, but also to organized public health [22] and reformers such as Charles Dickens, whose work was eagerly consumed by the increasingly literate masses. These social factors interacted and reinforced each other, creating a snowball effect, leading to a social "phase change".

Physical resources were vital to this progress, but so too were education, idealism, religious fervor, science, protest, redistribution, and reformers wary of the "old corruption" - the ruling class [23]. The "self-organization" of these and other factors remains relevant to contemporary global and planetary health.

\subsection{Saving American Capitalism}

In response to the Great Depression, itself a consequence of runaway capitalism, Franklin Roosevelt, the patrician U.S. president, introduced the New Deal, and then the second New Deal. This, with other policies, including incorporation by the government of many other Leftist ideas, weakened support for the American Communist Party and, some say, saved American capitalism [24,25]. From about 1933 until about 1970, and especially in the 1940s, wages of workers rose in the U.S., while incomes of the rich fell as taxes were increased [26]. Greater equality, favored by the policies of prominent economists such as J.M. Keynes and J.K. Galbraith snr, triumphed in the decades immediately after World War II. Reduced domestic inequality, in both Britain and the US, was also important to sustain morale during the war. The period of relative egalitarianism in the U.S. has been called the Great Compression [26].

Thus, in both Britain and the U.S., in the 19th and 20th centuries, respectively, it can be argued that inequality was lowered, at least temporarily, in order to avoid and to prevent an utter loss of elite privilege, such as occurred in France and Russia. In some cases, aristocrats may also have sincerely helped to support the cause of the common people ("noblesse oblige"-nobility obligates), motivated either by compassion, a sensing of these risks, or perhaps more likely, a combination of the two [27]. Philanthrocapitalists also emerged in this category; people such as Peter Cooper, Andrew Carnegie, John D. Rockefeller, Henry Wellcome, and, more recently, Bill Gates, George Soros, Warren Buffet and others (see Table 1) $[28,29]$. The fortunes of these entrepreneurs who became philanthrocapitalists accumulated due to the expansion in overall wealth that resulted from science, discovery and the conversion of nature (such as oil, land, minerals, and forests) to manufactured and agricultural goods. But these fortunes also accumulated, at least in Western countries, because of neoliberalism, the reversal of the Great Compression and the introduction of new norms which spurned taxation, good government, and public goods [9]. Few if any philanthrocapitalists accumulated their fortune during 
the Great Compression, a period of comparative self-restraint, as well as comparatively high taxation. (The bequest of Sir Henry Wellcome, who died in 1936, created what, until recently, was the world's largest health foundation). Note, also, that few if any philanthrocapitalists inherited their fortunes; they are not nobility or "old" money. Furthermore, many millionaires (more recently billionaires) don't even pretend to be generous to the poor, although some take advantage of tax incentives to support the arts, museums, or the environment, without claiming to promote any aspect of social justice. But some others work to undermine both democracy and environmental protection [30].

\subsection{Saving the World System}

A hat-trick of global catastrophes (the Great War, the Depression, and World War II [WWII]) led, in the mid-1940s, to the birth of the United Nations, the successor to the failed League of Nations. Apart from the opinion of cynics and Cold War bulldogs such as George Kennan [31], the UN, at least in its early decades, was widely regarded as a legitimate attempt to save the world system, or civilization as we know it [32] (see Appendix B).

During the Great Compression some forms of global inequality eased. For example, many nations were granted independence, although others, such as the former French colonies of Algeria and IndoChina, were not willingly let go, triggering savage wars with long-lasting consequences. The anticolonial war in Algeria also helped to inform and inspire the psychiatrist Franz Fanon, whose book The Wretched of the Earth [33] helped to raise awareness of the plight of people in what was still generally called the Third World [34].

The vindictiveness of Britain, France, and the U.S. that followed the "Great" War (World War I) saw Germany burdened with enormous debt and helped trigger a short-lasting peace, immediately foreseen as fragile by Keynes [35]. This mistake was not repeated after the second war. Instead, the Marshall Plan can be seen as a form of self-interested generosity by the U.S. which is widely credited as accelerating economic recovery in Western Europe, and which saw Germany emerge as a strong and durable U.S. ally (until the presidency of Donald Trump), rather than the adversary it became in the 1930s.

In Britain, the National Health Service (NHS) was introduced in 1948. Survivors of WWII voted out the Conservatives, cementing a bipartisan compact protective of the NHS that still exists, despite the sustained shift to the Right that occurred following the election of U.K. Prime Minister Margaret Thatcher in 1979. In many countries, including in the U.S., executives showed voluntary self-restraint with their salaries and bonuses, for about three decades after WWII, extending and consolidating the Great Compression [36]. However, today, in Britain [37], France, and the U.S., inequality is again rising, triggering major social reactions, including shifts towards nationalism and authoritarianism.

\subsection{The Rise and Decline of WHO as a Promoter of Global Health}

Adding to the trio of calamities that incubated the United Nations institutions, including the World Health Organization (WHO), was the "Spanish" influenza pandemic, which killed as many as 50 million people in the final years of World War I and the period immediately following it (when global population was fewer than 2 billion, compared to over 7.5 billion today) [38]. Some hypothesize that the unusual virulence of the responsible virus evolved in the appalling conditions of undernutrition, crowding, and mustard gas-damaged lungs that characterized the Great War's closing years, and which may have served inadvertently as a natural laboratory of biological warfare $[39,40]$.

One aim of WHO (founded in 1948) was to prevent such pandemics. Another was to improve health in developing countries, places today mostly called the Global South [34]. In 1955, for example, WHO launched a highly ambitious, ultimately unsuccessful campaign to eradicate malaria [41]. Twelve years later, WHO launched another eradication campaign, against smallpox [42]. Within only 11 years, that campaign proved successful. In 1988, in a third major vertical health project, WHO proposed to eradicate polio by the year 2000 [43]. However, eradication of smallpox was an easier 
target than either malaria or polio, though the achievement was still phenomenal; an unprecedented achievement that remains unique.

In its early decades, most WHO funding was discretionary (i.e., from the perspective of WHO), provided by member states as assessed dues in proportion to their income. The peak percentage of such discretionary funding was about two thirds in the 1960s [44]. The drive for WHO to promote health culminated in what Halfdan Mahler, the third WHO director general (1973-1988), called the "warm decade" of the 1970s [45]. In this decade, WHO launched its campaign of "Health for All by the Year 2000" $[45,46]$. Such a proposal would be unthinkable today, including because only about $20 \%$ of WHO's current spending is discretionary [44]. The 1978 Alma Ata conference proved to be the height of WHO's aspiration [47]. However, a more limited appeal for universality has re-emerged in WHO's call for universal coverage or access in a wide range of health-related areas including HIV / AIDS, reproductive health, health insurance, and free health services, particularly for women and children [48].

From the early 1980s, a shift occurred in the funding of WHO, in parallel to the rising influence of neoliberalism, or the doctrine that that market exchange is the supreme guide to economic prosperity and thus to human well-being $[9,49,50]$. It is probably not coincidental that around this time the number of influential people with vivid memories and deep understanding of the catastrophes that gave birth to the UN was declining, due to the ageing of the generation for which these experiences were formative. British sociologist Simon Szretzer likened the public acceptance of the alleged benefits of "trickle down" economics in western economies in this period, to a naïve prospector tricked by fool's gold [17].

Neoliberal policies, in conjunction with tightening Limits to Growth [4], have, at first gradually but now more rapidly, led to the undermining of many forms of support for many global public goods [51]. This slow cascade of consequences is still evolving, and has many manifestations. It is revealed, for example, by three recent unilateral U.S. decisions: announcing its withdrawal from the 2015 Paris climate change agreement (effective November 2020), its reneging on the Western alliance to quell Iranian nuclear aspirations, and its exit from the UN Human Rights Council [52]. The increasingly recognized failure of neoliberalism and associated doctrines to generate a fair distribution of health, income, and opportunity has generated rising nationalism, almost everywhere, and increased intolerance, in almost all high-income settings, for the record number of migrants, refugees, and displaced people.

An early casualty of the rise of post-WWII neoliberalism was the erosion of support for comprehensive primary health care, which was grounded in philosophies such as the importance of social and political determinants of health, knowledge-transfer and partnership [53,54]. Compounding this erosion was the gradual abandonment of horizontal health care approaches, and the suppression of knowledge that rapid population growth in poor settings helps to lock in poverty [55].

The pursuit of comprehensive primary health care was narrowed to "GOBI"—a strategy based on the four pillars of growth charts $(\mathrm{G})$, oral rehydration $(\mathrm{O})$, breast feeding $(\mathrm{B})$, and immunization (I) [56]. Then, support even for this ghost of comprehensive primary health care faltered. Funds for mass immunization in the global South dwindled [57] leading to a vaccine-funding shortfall that eventually helped to stimulate the Global Alliance for Vaccines and Immunization (GAVI), initially funded by the BMGF (see Box 2). 
Box 2. The vaccine crisis, Global Alliance for Vaccines and Immunization (GAVI), and the Bill and Melinda Gates Foundation (BMGF). Source: https://www.gavi.org/about/mission/history/ (accessed on 22 March, 2019).

“Bill and Melinda Gates added to the momentum by hosting a dinner at their home for leading scientists to discuss what could be done to overcome the barriers preventing millions of children from receiving basic vaccines. Bill and Melinda challenged their guests to come back with proposals for "breakthrough solutions."

“In March 1999, a second summit at Bellagio in northern Italy provided the answer to the Gates' challenge. Rather than setting up a new international organization, the existing major players in global immunization-the key UN agencies, leaders of the vaccine industry, representatives of bilateral aid agencies and major foundations-agreed to work together through a new partnership: the Global Alliance for Vaccines and Immunization (GAVI, the Vaccine Alliance)."

“The Vaccine Alliance's dream of delivering vaccines to millions of the world's poorest children moved a step closer to reality in November 1999, when the Gates Foundation pledged US\$ 750 million over five years to GAVI. Two months later, in January 2000, GAVI was formally launched at the World Economic Forum in Davos, Switzerland."

In 2002, as a result of the increasing use of market forces (and before the largely BMGF-driven revival of interest for global health had flowered), the annual budget of WHO was reported to be less than that spent on advertising by Coca Cola and PepsiCo combined [58]. In response to its widely perceived loss of status and influence [59] WHO sought and accepted a growing fraction of its support from private sources. Since 2000, funding for WHO has more than doubled, and this increase has come significantly from the private sector, led by the BMGF [44]. For the period 2015-2017, voluntary contributions to $\mathrm{WHO}$ accounted for $80 \%$ of its total income. Of the voluntary contributions, those of the BMGF (13.7\%) approached that of the U.S. (18\%) [44]. However, the fourth largest contributor to WHO in this period, at $\$ 112$ million per annum, was GAVI, which remains partly, perhaps substantially, dependent on the BMGF. Therefore, the contribution of the BMGF, directly and indirectly, to WHO may have exceeded the voluntary contribution of the U.S.

WHO's direction and policies are thus influenced by philanthrocapitalists, and by neoliberal governments, in ways that are unlikely to be widely understood by the public. Big pharmaceuticals and even beer barons have also been claimed to exert growing power over global health actors and policy [60]. While direct donations to WHO from drug companies are banned [61], Richard Horton recently asserted in 2018, that "the pharmaceutical industry is slowly colonizing global health in the same way that it has colonized clinical medicine" [60]. The loss of independence by WHO has been lamented by both the current WHO director general (Tedros Adhanom) and his predecessor, Margaret Chan, but so far, with little positive result [44,49]. In fact, Horton hints that, under Tedros (who prefers to be known by his first name), the problem is deepening [60].

\section{BMGF Characteristics Relevant to Global and Planetary Health}

\subsection{The Allegedly Hierarchical Structure of the BMGF}

The BMGF factsheet, as of November 14, 2018, proclaimed that "all lives have equal value" [62]. Yet, in 2011, it was reported that while the foundation has no mission statement, it has fifteen guiding principles, the first of which is that it is "driven by the interests and passions of the Gates family" [63]. A recent book describes the BMGF as "notoriously sealed" [64].

Open criticism of the BMGF by individuals, at risk of possibly resultant career damage, is hard to find, but some is documented. For example, in 2007 Margaret Chan, then WHO director general, endorsed a malaria eradication strategy seen at the time as a major reversal of global thought on this topic. She was reported to have done this without consulting her own senior malaria staff [65]. In the following year, Arata Kochi, a senior WHO malariologist, warned "many of the world's leading malaria scientists are now "locked up in a 'cartel" "with their own research funding being linked to 
those of others within the group". He complained to Chan that the BMGF money, while crucial, could have "far-reaching, largely unintended consequences" [66].

Storeng reports, of Bill Gates, that "while public health experts often privately criticised him for being incredibly strong-minded' and derided his techno-oriented approach as naive, Bill Gates is clearly venerated by many: 'When Bill speaks, people listen', she (Storeng) was frequently told. With Bill Gates at its helm, the Gates Foundation has surrounded itself with what one informant referred to as an 'aura of uncriticisability'" [67].

The extent of the allegedly hierarchical nature of the BMGF may hinder the pursuit of global and planetary health, which depend on collaboration and the reduction of inequality if great and enduring progress is to be made, a point clearly understood by the framers of the Ottawa Charter [47]. Reduced inequality is explicitly recognized in the tenth Sustainable Development Goal. It is naïve to imagine that one person (or one couple) can govern world health. Even if one person did have such solutions, conduits would be needed to disseminate that leader's influence in ways that motivate and inspire others. While authoritarian leaders indeed enforce their will over millions, or even a billion people, such influence is rarely benign. Gates may or may not have dictatorial tendencies, but the possibility that excessive inequality in the power structure of the BMGF is counterproductive to its stated aims remains true, particularly as Gates was not elected to his leadership position and faces no mandatory review. A recent book about the BMGF, which is sympathetic overall, comments that "one of the political issues in the Sustainable Development Goals on which the Gates Foundation and Bill Gates himself have been relatively silent is inequality" [64].

\subsection{The BMGF's Preference for Vertical Health Programs}

There is a long debate concerning "vertical" versus "horizontal" health care, dating at least to the 19th century. In reality, both approaches are useful $[68,69]$. The successful anti-smallpox campaign, led by $\mathrm{WHO}$, was a vertical program, largely conducted before the most recent phase of the global ascendancy of market-based economic approaches. The unsuccessful attempts to eradicate malaria, also led by WHO (1955-1969) [41], and polio, were also vertical.

The BMGF is disproportionately supportive of vertical health programs, focusing on a range of individual diseases, and a few syndromes, rather than seeking to improve health systems. The 2016 BMGF report details (of a total annual budget of US $\$ 4.6$ billion) expenditure of $\$ 3.9$ billion for global health, global development and global policy and advocacy. Of this, \$398 million is for agricultural development and $\$ 111$ million is for financial services for the poor. A further $\$ 513$ million is for "global advocacy". Of the balance ( $\$ 2.9$ billion), 38\% ( $\$ 1.08$ billion) is used for four conditions: polio, HIV / AIDS, malaria and tuberculosis. A further $\$ 458$ million (16\% of $\$ 2.9$ billion) is for vaccine delivery and development. Of the remainder, it is hard to find anything clearly targeted at strengthening health systems, although \$114 million is for "integrated" development and delivery. No funds seem directed at improving tertiary education of general (undifferentiated) health professionals in low income settings, nor for their continuing education.

Debate over the primacy of health care system approach is another example of the ideological divide within public health, echoing that about primary health care. The Norwegian government, which donates $1.1 \%$ of its gross national income to development assistance, is a strong supporter of a social (more horizontal) approach to public health. An analysis by Storeng of health systems and GAVI, funded by the Norwegian Research Council, concluded that "despite GAVI's self-proclaimed 'single-minded' focus on vaccines" health service strengthening (HSS) is now presented as a key GAVI principle. Storeng argues, however, that the meaning of HSS within GAVI is far from conceptualizations that emphasize social and political dimensions. She contends that GAVI's support for HSS "has become emblematic of the so-called 'Gates approach' to global health, focused on targeted technical solutions with clear, measurable outcomes. In spite of adopting rhetoric supportive of 'holistic' health systems, global health initiatives like GAVI have come to capture the global debate about HSS in favor of their disease-specific approach and ethos" [67]. A recent analysis reports increased engagement of GAVI 
(and the Global Fund) with health systems in countries afflicted by conflict, but finds mixed results, including burdensome reporting [70].

More positive evaluations of GAVI and health system strengthening exist. An article generally critical of the risks to health systems from global health actors (for example by the introduction of salary differentials that create staffing gaps and that undermine the morale of less differentiated health providers) argues that GAVI-associated health system strengthening can not only improve vaccine coverage but also improve other health aspects [68]. However, the authors of this paper make no attempt to argue that health systems strengthening should have any overt political dimension or transformational aspiration.

Storeng quotes a colleague of Bill Gates as saying that he (i.e., Gates) "often" told him privately that he 'is vehemently against health systems ... he basically said it is a complete waste of money, that there is no evidence that it works, so I will not see a dollar or cent of my money (sic) go to the strengthening of health systems'. Storeng also claims that "the Gates Foundation has encouraged the international maternal health community to focus on 'magic bullets' like antibiotics to prevent maternal deaths, despite maternal health specialists' insistence that general health system strengthening is required to reduce maternal mortality" [67].

The BMGF claim to be evidence-driven, and Gates is reported as claiming that evidence for investing in health systems is lacking. However, this would be difficult to test. McPake et al. point out that world's third largest Ebola outbreak to date, in Uganda in 2001, was substantially contained due to the faith-based efforts of the St Mary Lacor hospital in Gulu, a hospital that had operated for decades, including as a haven in a zone of conflict. This contributed to high levels of trust that strengthened its role during the outbreak [71].

Practitioners working in the North but trained in the South are an important source of remittances to the South. However, most remittances go to family members rather than to more collective means to elevate development, and some argue that remittances can worsen inequality [72]. Other factors, many systemic (such as corruption and ethnic and other forms of rivalry) in most supplying countries help to maintain the differential of attraction, which is not only financial. Many skilled health practitioners trained in the South have nonmonetary reasons to seek employment in the North, such as better working conditions (e.g., reliable medical supplies and steady electricity) or to escape discrimination or violence. A lower workload (or at least more rewards for hard work) and a healthier population may also be attractors. If the BMGF invested a small fraction of its budget to reward, retain, and equip dedicated, locally trained staff, not only of doctors and nurses, but also outreach workers and laboratory staff, and as part of a health system, rather than a disease-focused vertical program, would it have a long-lasting and beneficial effect?

\subsection{The BMGF's Focus on Technology, Especially Vaccines}

Another related criticism of the BMGF is its preference for technological, rather than social solutions $[73,74]$. Storeng quotes a vaccine expert she interviewed as stating "I think it is Mr Gates himself who sort of believes that the world can be cured by technology" [67]. Technology supported by the BMGF include vaccines, drugs, and diagnostic technologies for tuberculosis [75], to identify spoiled milk and "infected" maize [75] (perhaps maize contaminated with aflatoxins, a growing problem exacerbated by climate change) [76].

In addition to establishing GAVI, the BMGF provided the impetus for the organizations PATH (Program for Appropriate Technology in Health), PATH Drug Solutions, and PATH Vaccine Solutions, which by 2014 were reported to have received over US\$1.6 billion in grants [28]. The 2016 BMGF report shows that of its $\$ 2.4$ billion for direct global health programs (as defined above), $\$ 458 \mathrm{M}(19.1 \%)$ was spent on vaccine development and vaccine delivery. There are many strong supporters for new vaccines, which, to advocates, promise to reduce poverty [77]. Many vaccines have long been hoped for, such as for malaria, HIV and dengue. But although good progress has been made with some, 
including against rotavirus, meningitis A [77], and—possibly—Ebola [78], their delivery is slowed by the high cost of trials in settings that are not commercially viable [77].

In some cases, there may be cheaper ways to address the health problem. For example, trials of a pneumonia vaccine in the Gambia concluded that 1,000 children have to be vaccinated to prevent 3.6 cases of radiologically confirmed pneumonia [79]. Dabade and Puliyel pointed out that, at $\$ 250$ per child, this would cost $\$ 250,000$; whereas treatment of four children with pneumonia using oral cotrimoxazole, in accordance with the WHO protocol at that time, would cost $\$ 1$ in India [80]. When considering the trial introduction of a malaria vaccine (developed by GlaxoSmithKline, and called Mosquirix) the WHO's Strategic Advisory Group of Experts on Immunization and the Malaria Policy Advisory Committee called for caution, for reasons including its low efficacy, its need for four doses, and its expense [81]. Caution was also supported by the medical charity Medecins Sans Frontieres [81]. Unfortunately, in addition to fake drugs [82], a number of fake vaccines are in circulation, including against meningococcal disease [82].

Technology, including vaccines, is essential to promote world health, but the issue is one of balance. Human development, the rule of law and the establishment and strengthening of institutions may rival or be of greater importance than technology. If "soft", social mechanisms can be nurtured, then poor societies may themselves more effectively organize and engineer their escape from extreme poverty. Such a society may, for example, then be in an improved situation to identify and prohibit the circulation of fake drugs and vaccines. They may also be better able to improve nutrition in children, such as by reducing the consumption of "empty calories", and postpone the onset of noncommunicable diseases which, in many parts of the global South, also reduces health.

The BMGF regularly funds "grand challenges" in public health. This, too, has been criticized. Birn argues that the winners who perform "bold" and "unorthodox" research projects are rewarded "only if they view health in circumscribed, technological terms, not through integrated technical and socio-political understandings" [28]. The skills needed to promote and even to perceive the importance of social contributions to health are likely to be significantly different to that required for vaccine development and other technological approaches. The debate may not be fully resolvable, in the same way as adherents of neoliberalism appear to see the world so differently to redistributionists. But, in fact, both approaches may be necessary, to promote poverty-reducing synergisms.

\subsection{The BMGF's Use of Self-Funded Metrics as a Way to Measure But Perhaps Not Solve the Problem}

The BMGF is a strong supporter for health metrics, as is another neoliberal-friendly strategy to promote global health, called "effective altruism" $[29,83]$. The BMGF provided the seed funding, in 2007, for the Institute for Health Metrics and Evaluation, at the University of Washington, U.S., providing US\$105 million over five years [84]. One of the BMGF's grand challenges refers to health metrics. However, like technology, the issue is of dose. Evidence based priorities, while useful, may become fetishized, perpetuating their own existence, at the cost of intervention and solution. Furthermore, description and numbers are rarely, if ever, value free $[85,86]$. The methods used to calculate the global burden of disease studies have been described as "increasingly complex and incomprehensible even to global health experts" [87]. An additional problem is that the main source of the metrics the BMGF relies on is itself funded by the BMGF.

\subsection{The Co-Option of Independence by the BMGF}

It is not just WHO which has lost much of its independence. The power of the BMGF (and Wellcome and perhaps other funders) is so great that some researchers feel inhibited to offend them. The BGMF provides millions of dollars to researchers based in elite academic institutions in the U.K. and U.S. including in London, Liverpool (U.K.), and (in the U.S.) to Columbia, Harvard, Johns Hopkins, and the University of Washington [84]. It supports the agricultural program called Gender-responsive Researchers Equipped for Agricultural Transformation (GREAT), at another leading (also handsomely endowed) U.S. university, Cornell, as well as the Cornell Alliance for Science, an aim of which is to 
"depolarize" the discussion about genetically modified organisms [88]. The BMGF even helps support the World Bank [84], long criticized for its dominant role in promoting neoliberalism [89].

The primary constitutional mission of WHO is said to be leadership [90]. But is this possible when so much of WHO is controlled by outside forces?

\subsection{Conflicts of Interest of the BMGF and Other Philanthrocapitalists}

Another common criticism of philanthrocapitalism is of conflicts of interest. These arise and persist due to their investment in corporations, some of which may "exacerbate or perpetuate social and economic inequalities and ills that they purport to remedy" [29]. These ills include to the environment, and thus to planetary health. For example, an investigation by the Los Angeles Times reported that the BMGF were investing in a large petroleum company bases in the Niger Delta, an area long notorious for oil contamination and poverty [91]. Nnimmo Bassey, a recipient of the 2010 Right Livelihood Award for his work on publicizing the plight of people of the Niger delta, commented (in relation to the BMGF) that "If this is a charity that really care about the health of the people, they ought not to be investing in fossil fuel industries. They should pull back their resources from this sector completely" [92].

The BMGF used to and may still invest in corporations that profit from junk food, such as Coca-Cola and McDonalds [63]. The company Berkshire Hathaway, associated with Warren Buffett, who has pledged most of his fortune to the BMGF, has also been reported as a major investor in Coca-Cola [63]. There is strong evidence, including from leaked documents, that Coca-Cola has covertly acted to disguise the harm to public health from its commercial activities [93], in addition to promoting demand for unhealthy products [94]. Thus, on one hand BMGF and Buffett act to improve global health; but on the other they have and possibly still continue to invest in corporations which undermine global health. At times, though, the BMGF have behaved in a way this author considers ethical and admirable. For example, in 2010 the BMGF withdrew a grant of U.S.\$5.2 million to Canada's International Development Research Centre, after it emerged that its chair, Barbara McDougall, was then a very recent board member of Imperial Tobacco Canada [95].

The Gates charity investment policy was reported (in 2015) as stating: "Bill and Melinda consider issues beyond corporate profits, including the values that drive the foundation's work. They have defined areas in which the endowment will not invest, such as companies whose profit model is centrally tied to corporate activity that they find egregious" [92]). In 2019, it uses the same terms, identifying, as examples, tobacco and stocks related to Sudan (see Appendix C).

The BMGF have conflicts of interest policies, but the main problem described here cannot be solved even if these conflict of interest rules are scrupulously observed. No evidence is here presented that the BMGF profits directly from practices that overtly exploit populations in the Global South (and it is not implicated in the Paradise Papers) [96]. However, exploitation of the poor, including in the South, is taken for granted by supporters of market forces (though rarely spoken of as bluntly) [97]. Such exploitation is inherent to global capitalism, including the practices of many fashionable clothes manufacturers [98] and Apple, the manufacture of iPhones [99].

Bill Gates, in response to criticism from Anand Giridharadas (author of "Winners Take All: The Elite Charade of Changing the World" [100]) spoke at the World Economic Forum in 2019 in favor of "tuning" the system, including towards greater equality, however the extent of such tuning was unclear [101]. Yet, Gates also appeared to characterize an alternative system as Communism, in so doing misrepresenting the calls by so many, including Nobel laureates in economics [83,102], for a much fairer version of capitalism, rather than an intensifying gilded age [103].

\section{Carbon, Divestment, Philanthrocapitalism, and Planetary Health}

In 2015, an analysis of the 2013 BMGF tax filing from was reported as revealing that the foundation then held at least US $\$ 1.4$ billion in fossil fuel investments, although it has been reported since as greatly reducing this [104]. The same media report quoted a spokesman for Bill Gates's private office as saying: 
"We respect the passion of advocates for action on climate change, and recognise that there are many views on how best to address it. Bill is privately investing considerable time and resources in the effort [to develop clean energy]" [104].

The investments of the Wellcome Trust (also philanthrocapitalist, and the world's largest medical research foundation until surpassed by the BMGF), which also invests in Berkshire Hathaway, may be even more problematic. For example, according to the trove of leaked documents known as the Paradise Papers, the Wellcome Trust was revealed as a major investor (almost US $\$ 1$ billion) in tax havens [96]. However, less opaquely, the Wellcome Trust continues to vigorously invest in fossil fuels, as is described below.

Holding shares in a corporation is a form of support. No rational actor will invest in a company that it expects to experience falling market share, though of course such a possibility always exists. It follows, therefore, that the BMGF and Wellcome think the companies they invest in will continue to do well financially. But it is very hard to avoid concluding that such investors also want such companies to prosper, even if this is justified by the "greater good" argument used by Mother Teresa. Also, perhaps, investment in such companies requires tacit (or explicit) moral support for their practices.

This "ends" versus "means" debate is old. Mother Teresa was criticized for placing flowers on the grave of the Albanian dictator Hoxha [105]. In exchange, Albanian-born Teresa received support. It was once common practice for many universities, including Cambridge, to accept tobacco money for research [106]. It is also central to the debate over "effective altruism" which has been described as "doing well to do good" [29], even if "doing well" involves profit from unethical, though legal practices. The Wellcome Trust, in response to criticism, is unapologetic, noting that its investments fuel good works. Critics point out that foundations that invest in tax havens helps normalize tax evasion [96].

William MacAskill, a critic of divestment, argues that the primary purpose of divestment is to lower the price of stocks, although he does admit that stigmatization is a secondary purpose. Like the Wellcome Trust, MacAskill appears indifferent to the moral argument for divestment, defending the BMGF's history of investment in prisons [107]. (The BMGF may have since divested from private prisons, as it has been reported as selling its stake in security company G4S, following controversy over its prison contracts in Israel) [92].

The Wellcome Trust, a prominent example of philanthrocapitalism, recently made grants of UK£75 million to promote its vision of ecological public health. More grants are planned. This is encouraging. It is thus deeply unfortunate that this work is undermined by the Trust's continuing investment in fossil fuels, despite a vigorous campaign against this from segments of the health community [108].

The Rockefeller Foundation, an earlier example of philanthrocapitalism (also very generous to world health), has been an early and important supporter of both the Planetary Health Alliance $[14,109,110]$ and the Global Consortium on Climate Change and Health Education [111]. In 2014 the Rockefeller Foundation pledged to divest from fossil fuels, citing "moral tension". By December 31, 2018 the Fund's exposure to coal and tar sands had been reduced to less than 0.2 percent of its total portfolio, and its total fossil fuel exposure was estimated to be 1.3 percent, falling from 6.6\% in April 2014 [112]. In the past, however, the actions of the Rockefeller Foundation were not blameless; for example, by their involvement in studies undertaken, without informed consent, in which children, prison inmates, psychiatric patients, soldiers, and orphans were intentionally infected with syphilis, gonorrhea, chancroid, and other diseases, over the period 1945-1956 [113].

The BMGF, as yet, has no program in ecological or planetary health comparable to that of the Wellcome Trust. In a long interview published in The Atlantic, Bill Gates seemed to cast doubt on the urgency of climate change, for example claiming that El Niño "has a much bigger impact on current weather than climate change has had so far" [114]. This statement seems to discount the many other harmful effects of greenhouse gas accumulation, such as the impact that sea level rise is having on low-lying coastal areas and house prices [115]. It also ignores the possibility that climate change may strengthen the impact of both El Niño and its counterpart, La Niña [116,117]. 
Although the BMGF, as mentioned, has now largely divested from fossil fuel, Gates has been critical of the carbon divestment movement $[114,118]$. He is also on record as being skeptical about the potential for an energy transition based on solar and wind energy, due to what he perceives as an overwhelming problem of energy storage [119]. Gates is a major investor in so-called "next generation" nuclear power to lower the risk of climate change [120]. The BMGF also supports research into attempting to boost the capacity of photosynthesis, but not necessarily micronutrient concentration and overall nutritional quality [121,122].

These are highly ambitious, largely technological approaches to climate change. But the absence, so far, of BMGF investment in ecological public health (or planetary health), suggests that it does not yet see Earth system change as having the potential to cripple global health, on a planetary scale. Similarly, the Wellcome Trust's approach to planetary health is undermined by its substantial investment in fossil fuels. This action signifies that it, too, underestimates the fearsome risk to civilization from excessive modification of the Earth system, one risk of which is runaway warming leading to a "hothouse" Earth [123].

\section{Conclusions}

This review has primarily focused on the BMGF and its relationship to global and planetary health. Philanthrocapitalism is a product of neoliberalism and privilege, in a world in which global inequality is very high, and increasingly in parts, grotesque. It is not surprising that philanthrocapitalist organizations have at times attracted virulent criticism. A recent paper argues that a "theodicy of privilege" has obfuscated critical examination of philanthrocapitalism. Its authors claim that "it is laudable and even dutiful for immiserated workers to salute the donor class for directing its philanthropy at itself" [27]. Bloom and Rhodes have characterized philanthrocapitalism as "the transfer of responsibility for public goods and services from democratic institutions to the wealthy, to be administered by an executive class" [124]. Eikenberry and Mirabella argue that "neoliberal ideology has pervaded social discourse to such a degree that most celebrate and only a rare few question the actions of philanthrocapitalists who assume that there is no conflict between making money and making change" [29].

There is currently little evidence to support the view that forms of human organization other than philanthrocapitalism can do a better job at promoting global health, particularly given the currently strong influence of neoliberalism. WHO successfully eradicated smallpox, and, in the same decade, declared "health for all". It failed in this second aspiration, in part because of the overwhelming power of counteracting social and economic forces. All organizations also face the problem of the "last mile". A wise WHO director general based in Geneva needs a partner in Liberia (and elsewhere) to implement reform; it cannot happen by wishing.

The milieu in many parts of the South contain thick impedimentary layers: not only poverty, but divided allegiances, limited education, and competing priorities. Even if the agent in the South is skilled, they too have their own "last mile" challenge. At some point, especially in the South, attempts to promote excellent health are likely to founder, especially if sufficient factors to generate local "take off" are lacking. Such factors may include nutrition, education, healthcare, and governance. A vertical health system, on its own, is unlikely to be sufficient to solve these difficult problems. Greater attention to horizontal health care is also needed.

The Wellcome Trust (which, as stressed, has not yet divested in fossil fuels) is now providing research funds to promote its vision of ecological public health. Paradoxically, the BMGF, which appears to have almost completely divested from fossil fuels, does not yet do this. However, if the Earth's eco-social system crosses a critical threshold then civilization will founder; all will be lost $[7,125]$. The old scourges of malaria, polio, tuberculosis, HIV/AIDS, influenza and plague could then roar back [40], accompanied by famine, conflict, and probably totalitarianism in places that still have order [126]. It is a specter that should be feared and avoided. Capitalism may be able to coexist with civilization's sustainability, but it needs radical reform to enhance this chance. 
The BMGF and other philanthrocapitalists need to demonstrate courage; to pursue and advocate for transformational change.

Funding: This research received no external funding.

Acknowledgments: My thanks to Dr Carol Colfer, five anonymous reviewers, and the editor.

Conflicts of Interest: The authors declare no conflict of interest.

\section{Appendix A}

Table 2 is a synthesis arising from over 3 decades of my engagement in these fields. For example, two edited books, for which I was sole or senior editor, largely concern global and planetary health. These are called "Climate Change and Global Health" (CABI, 2014, 2016) and "Health of People, Places and Planet: Reflections Based on Tony McMichael's Four Decades of Contribution to Epidemiological Understanding" (ANU Press 2015). I was a co-ordinating lead author for the Millennium Ecosystem Assessment (conceptual framework and future scenarios for human well-being). I have been a keynote speaker at several relevant international conferences, including EcoHealth (2008), climate change in the South East Asian Region of WHO (2009), One Health $(2011,2012)$ and the second ASEAN conference on biodiversity (2016). I was the only Australian reviewer of the Rockefeller Foundation-Lancet Commission on Planetary Health. In 2006-07 I was employed to establish a new Master's degree on Global Health at Deakin University, Australia (the first such proposed course in Australia). From 2009-13 I was one of 4 co-editors for the journal EcoHealth. I have published, starting in 1994, often as first $(20 \%)$ or sole $(40 \%)$ author, about 150 articles and chapters relevant to both Global Change and Planetary Health, in addition to letters and other scholarly contributions. These include a forthcoming entry on "planetary health" in the International Encyclopedia of Human Geography. In addition, I co-founded two NGOs, each now in their 30th year, which promote health in low-income settings in several Asian nations. I also spent most of a year, in 1985, as a medical student in health work in low income settings in three "developing" countries (Nigeria, Nepal and India). My PhD "Inequality and Sustainability" (completed in 2002) was highly relevant to global environmental change and health, and thus planetary health. I also have training and qualifications in tropical medicine and hygiene (acquired in London, in 1990). My recent papers and book chapters focusing on planetary health are increasingly critical of its insufficient engagement with issues of political economy, as well as its avoidance of issues such as conflict.

\section{Appendix B}

Kickbusch writes in part: "At the World Financial Summit, on Nov 15 (2008), there seem to be few taboos as to what will be under discussion, including a redefinition of capitalism. Many of the suggestions currently put forward by the political elite to address the agendas of the 21st century have been voiced by critics of the present financial system, by developing countries, and by non-governmental organisations for years. Until recently, these critics have condescendingly been considered as Utopians and ideologues. When, for example, the final report by WHO's Commission on Social Determinants of Health stated that "Implementation of the Commission's recommendations depends on changes in the functioning of the global economy", a review in The Economist responded that the Commission "seems, at times, to be baying at the moon when it attacks global imbalances in the distribution of power and money. Who is baying now?"

\section{Appendix C}

On March 22, 2019 the investment policy page for the BMGF stated "When instructing the investment managers, Bill and Melinda also consider other issues beyond corporate profits, including the values that drive the foundation's work. They have defined areas in which the endowment will not invest, such as companies whose profit model is centrally tied to corporate activity that they find 
egregious. This is why the endowment does not invest in tobacco or Sudan-related stocks." Source: http s:/ / www.gatesfoundation.org/Who-We-Are/General-Information/Financials/Investment-Policy.

\section{References}

1. Bishop, M. Philanthrocapitalism: Solving public problems through private means. Soc. Res. 2013, 80, 473-490.

2. Butler, C.D. Planetary health. In International Encyclopedia of Human Geography; Kobayashi, A., Ed.; Elsevier: Amsterdam, The Netherlands, in press.

3. Prescott, S.L.; Logan, A.; Albrecht, G.; Campbell, D.; Crane, J.; Cunsolo, A.; Holloway, J.; Kozyrskyj, A.; Lowry, C.; Penders, J.; et al. The Canmore Declaration: Statement of principles for planetary health. Challenges 2018, 9, 31. [CrossRef]

4. Butler, C.D. Limits to growth, planetary boundaries, and planetary health. Curr. Opin. Environ. Sustain. 2017, 25, 59-65. [CrossRef]

5. Koplan, J.P.; Bond, T.C.; Merson, M.H.; Reddy, K.S.; Rodriguez, M.H.; Sewankambo, N.K.; Wasserheit, J.N. Towards a common definition of global health. Lancet 2009, 373, 1993-1995. [CrossRef]

6. Prescott, S.L.; Logan, A.C. Larger than life: Injecting hope into the planetary health paradigm. Challenges 2018, 9, 13. [CrossRef]

7. Horton, R.; Beaglehole, R.; Bonita, R.; Raeburn, J.; McKee, M.; Wall, S. From public to planetary health: A manifesto. Lancet 2014, 383, 847. [CrossRef]

8. Butler, C.D. Climate change, health and existential risks to civilization: A comprehensive review (1989-2013). Int. J. Environ. Res. Public Health 2018, 15, 2266. [CrossRef]

9. Labonté, R.; Stuckler, D. The rise of neoliberalism: How bad economics imperils health and what to do about it. J. Epidemiol. Community Health 2016, 70, 312-318. [CrossRef] [PubMed]

10. Myers, S.S. Planetary health: Protecting human health on a rapidly changing planet. Lancet 2017, 390, 2860-2868. [CrossRef]

11. Salk, J.D. Planetary health: A new reality. Challenges 2019, 10, 7. [CrossRef]

12. Essack, S.Y. Environment: The neglected component of the One Health triad. Lancet Planet. Health 2018, 2, e238-e239. [CrossRef]

13. Hansen, J. Scientific reticence and sea level rise. Environ. Res. Lett. 2007, 2, 024002. [CrossRef]

14. Whitmee, S.; Haines, A.; Beyrer, C.; Boltz, F.; Capon, A.G.; de Souza Dias, B.F.; Ezeh, A.; Frumkin, H.; Gong, P.; Head, P.; et al. Safeguarding human health in the Anthropocene epoch: report of The Rockefeller Foundation-Lancet Commission on planetary health. Lancet 2015, 386, 1973-2028, Supplementary appendix 1. Available online: https:/ /www.thelancet.com/journals/lancet/article/PIIS0140-6736(15)60901-1/fulltext (accessed on 22 March 2019).

15. Butler, C.D. Inequality and conflict. In In Search of Sustainability; Goldie, J., Douglas, R.M., Furnass, B., Eds.; CSIRO: Melbourne, Australia, 2005; pp. 33-48.

16. Harper, K. The Fate of Rome; Princeton University Press: Princeton, NJ, USA, 2017; p. 440.

17. Szreter, S. Economic growth, disruption, deprivation, disease and death: On the importance of the politics of public health. Popul. Dev. Rev. 1997, 23, 693-728. [CrossRef]

18. Davis, M. Late Victorian Holocausts: El Nino Famines and the Making of the Third World; Verso: London, UK, 2001; p. 464.

19. Patnaik, U. The Free Lunch-Transfers from the Tropical Colonies and Their Role in Capital Formation in Britain during the Industrial Revolution. In Globalization under Hegemony; Jomo, K.S., Ed.; Oxford University Press: Delhi, India, 2008.

20. Szreter, S.; Mooney, G. Urbanization, mortality and the standard of living debate: New estimates of the expectation of life at birth in nineteenth-century British cities. Econ. Hist. Rev. 1998, 51, 84-112. [CrossRef]

21. McKeown, T.; Record, R.G. Reasons for the decline of mortality in England and Wales during the nineteenth century. Popul. Stud. 1962, 16, 94-122. [CrossRef]

22. Hamlin, C. Public Health and Social Justice in the Age of Chadwick: Britain 1800-1854; Cambridge University Press: Cambridge, UK, 1998; p. 388. 
23. Szreter, S. Rapid economic growth and the four Ds of disruption, deprivation, disease and death: Public health lessons from 19th-century Britain for 21st-century China? Trop. Med. Int. Health 1999, 4, 146-152. [CrossRef] [PubMed]

24. Amenta, E.; Dunleavy, K.; Bernstein, M. Stolen thunder? Huey Long's "Share Our Wealth," political mediation, and the second New Deal. Am. Sociol. Rev. 1994, 59, 678-702. [CrossRef]

25. Lipset, S.M.; Marks, G. It Didn't Happen Here: Why Socialism Failed in the United States; W. W. Norton: New York, NY, USA, 2001.

26. Goldin, C.; Margo, R.A. The Great Compression: The wage structure in the United States at mid-century. Quart. J. Econ. 1992, 107, 1-34. [CrossRef]

27. McGoey, L.; Thiel, D. Charismatic violence and the sanctification of the super-rich. Econ. Soc. 2018, 47, 111-134. [CrossRef]

28. Birn, A.-E. Philanthrocapitalism, past and present: The Rockefeller Foundation, the Gates Foundation, and the setting(s) of the international/global health agenda. Hypothesis 2014, 12, e6. [CrossRef]

29. Eikenberry, A.M.; Mirabella, R.M. Extreme philanthropy: Philanthrocapitalism, effective altruism, and the discourse of neoliberalism. PS Political Sci. Politics 2018, 50, 43-47. [CrossRef]

30. Schulman, D. Sons of Wichita: How the Koch Brothers Became America's Most Powerful and Private Dynasty; Hachette Book Group: New York, NY, USA, 2014; p. 378.

31. Costigliola, F. “Unceasing pressure for penetration”: Gender, pathology, and emotion in George Kennan's formation of the Cold War. J. Am. Hist. 1997, 83, 1309-1339. [CrossRef]

32. Kickbusch, I. Baying at the moon: Addressing the politics of global health. Lancet 2008, 372, $1623-1624$. [CrossRef]

33. Fanon, F. The Wretched of the Earth; Grove Press: New York, NY, USA, 1963; p. 255.

34. Butler, C.D. The North and South. In International Encyclopedia of the Social Sciences; Hedblad, A., Ed.; MacMillan Reference: New York, NY, USA, 2007; Volume 5, pp. 542-544.

35. Keynes, J.M. The Economic Consequences of the Peace; Macmillan: London, UK, 1919; p. 279.

36. Krugman, P. The great wealth transfer. Rolling Stone. 2006. Available online: http://www.rollingstone.com /politics/story/12699486/paul_krugman_on_the_great_wealth_transfer (accessed on 17 March 2019).

37. Anonymous. Poverty is a political choice. Lancet Public Health 2018, 3, Pe555.

38. Taubenberger, J.K.; Morens, D.M. 1918 influenza: The mother of all pandemics. Emerg. Infect. Dis. 2006, 12, 15-22. [CrossRef]

39. Oxford, J.S.; Sefton, A.; Jackson, R.; Innes, W.; Daniels, R.S.; Johnson, N.P.A.S. World War I may have allowed the emergence of "Spanish" influenza. Lancet Infect. Dis. 2002, 2, 111-114. [CrossRef]

40. Butler, C.D. Infectious disease emergence and global change: Thinking systemically in a shrinking world. Infect. Dis. Poverty 2012, 1, 5. [CrossRef]

41. Nájera, J.A.; González-Silva, M.; Alonso, P.L. Some lessons for the future from the global malaria eradication programme (1955-1969). Public Libr. Sci. Med. 2011, 8, e1000412. [CrossRef] [PubMed]

42. Fenner, F. The Florey Lecture, 1983-Biological control, as exemplified by smallpox eradication and myxomatosis. Proc. R. Soc. B 1983, 218, 259-285.

43. Blume, S.; Geesink, I. A brief history of polio vaccines. Science 2000, 288, 1593-1594. [CrossRef] [PubMed]

44. Clift, C.; Røttingen, J.-A. New approaches to WHO financing: The key to better health. BMJ 2018, $361, \mathrm{k} 2218$. [CrossRef] [PubMed]

45. Brown, H. Great expectations. BMJ 2007, 334, 874-876. [CrossRef]

46. Litsios, S. The long and difficult road to Alma-Ata: A personal reflection. Int. J. Health Serv. 2002, 32, 709-732. [CrossRef] [PubMed]

47. Butler, C.D.; Friel, S. Time to regenerate: Ecosystems and health promotion. Public Libr. Sci. Med. 2006, 3, e394. [CrossRef]

48. Gwatkin, D.R.; Ergo, A. Universal health coverage: Friend or foe of health equity? Lancet 2011, 377, $2160-2161$. [CrossRef]

49. Legge, D. Future of WHO hangs in the balance. BMJ 2012, 345, e6877. [CrossRef]

50. Benatar, S.; Upshur, R.; Gill, S. Understanding the relationship between ethics, neoliberalism and power as a step towards improving the health of people and our planet. Anthr. Rev. 2018, 5, 155-176. [CrossRef]

51. McMichael, A.J.; Butler, C.D.; Ahern, M.J. Global environment. In Global Public Goods for Health; Smith, R., Beaglehole, R., Woodward, D., Drager, N., Eds.; Oxford University Press: Oxford, UK, 2003; pp. $94-116$. 
52. Borger, J. US quits UN human rights council-'A cesspool of political bias'. The Guardian. 2018. Available online: https:/ / www.theguardian.com/world/2018/jun/19/us-quits-un-human-rights-council-cesspoo 1-political-bias?utm_source=esp\&utm_medium=Email\&utm_campaign=GU+Today+AUS+v1+-+AUS+ morning+mail+callout\&utm_term=278555\&subid=24577741\&CMP=ema_632 (accessed on 16 March 2019).

53. Werner, D.; Sanders, D. Questioning the Solution: The Politics of Primary Health Care and Child Survival; HealthWrights: Palo Alto, CA, USA, 1997; p. 206.

54. King, M. Medical Care in Developing Countries. A Primer on the Medicine of Poverty and a Symposium from Makerere; Oxford University Press: Nairobi, Kenya, 1966; p. 416.

55. Butler, C.D.; Higgs, K. Health, population, limits and the decline of nature. In The Sage Handbook of Nature; Marsden, T., Ed.; Sage: London, UK, 2018; pp. 1122-1149.

56. Wisner, B. GOBI versus PHC? Some dangers of selective primary health care. Soc. Sci. Med. 1988, 26, 963-969. [CrossRef]

57. Cutts, F. Vaccination in the 21st century-new funds, new strategies? Trop. Med. Int. Health 2000, 5, 57-59. [CrossRef]

58. Lang, T.; Rayner, G.; Kaelin, E. The food industry, diet, physical activity and health: A review of reported commitments and practice of 25 of the world's largest food companies. Report to the World Health Organization. City University Centre for Food Policy, 2006. Available online: https://www.academia.edu/1849841/The_food_industry_diet_physical_activity_and_health_a _review_of_reported_commitments_and_practice_of_25_of_the_worlds_largest_food_companies (accessed on 17 March 2019).

59. Godlee, F. WHO in crisis. BMJ 1994, 309, 1424-1428. [CrossRef]

60. Horton, R. Offline: Global health and the private sector. Lancet 2018, 391, 2196. [CrossRef]

61. Day, M. Who's funding WHO? BMJ 2007, 334, 338. [CrossRef]

62. Gates Foundation. Factsheet. 2018. Available online: https://www.gatesfoundation.org/Who-We-Are/Gen eral-Information/Foundation-Factsheet (accessed on 14 November 2018).

63. Stuckler, D.; Basu, S.; McKee, M. Global health philanthropy and institutional relationships: How should conflicts of interest be addressed? Public Libr. Sci. Med. 2011, 8, e10010200. [CrossRef]

64. Fejerskov, A.M. The Gates Foundation's Rise to Power: Private Authority in Global Politics, 1st ed.; Routledge Studies in Development and Society: London, UK, 2018; p. 212.

65. Roberts, L.; Enserink, M. Did they really say eradication? Science 2007, 318, 1544-1545. [CrossRef]

66. McNeil, D.G., Jr. Gates Foundation's influence criticized. New York Times. 2008. Available online: https: / / www.nytimes.com/2008/02/16/science/16malaria.html (accessed on 17 March 2019).

67. Storeng, K.T. The GAVI Alliance and the 'Gates approach' to health system strengthening. Glob. Public Health 2013, 9, 865-879. [CrossRef]

68. Marchal, B.; Cavalli, A.; Kegels, G. Global health actors claim to support health system strengthening-Is this reality or rhetoric? Public Libr. Sci. Med. 2009, 6, e1000059. [CrossRef]

69. Bärnighausen, T.; Bloom, D.; Humair, S. Going horizontal — shifts in funding of global health interventions. N. Engl. J. Med. 2011, 364, 2181-2183. [CrossRef]

70. Patel, P.; Cummings, R.; Roberts, B. Exploring the influence of the Global Fund and the GAVI Alliance on health systems in conflict-affected countries. Conf. Health 2015, 9, 7. [CrossRef] [PubMed]

71. McPake, B.; Witter, S.; Ssali, S.; Wurie, H.; Namakula, J.; Ssengooba, F. Ebola in the context of conflict affected states and health systems: Case studies of Northern Uganda and Sierra Leone. Conf. Health 2015, 9, 23. [CrossRef]

72. Le De, L.; Gaillard, J.C.; Friesen, W. Poverty and disasters: Do remittances reproduce vulnerability? J. Dev. Stud. 2015, 51, 538-553. [CrossRef]

73. McCoy, D.; McGoey, L. Global Health and the Gates Foundation - In Perspective. In Partnerships and Foundations in Global Health Governance; Rushton, S., Williams, O.D., Eds.; Palgrave Macmillan: London, UK, 2011; pp. 143-163.

74. Birn, A.-E. Gates's grandest challenge: Transcending technology as public health ideology. Lancet 2005, 366, 514-519. [CrossRef]

75. Gates Foundation. Bill \& Melinda Gates Foundation Awards $\$ 10$ Million To Develop New Diagnostics for Tuberculosis. 2011. Available online: https:/ /www.gatesfoundation.org/Media-Center/Press-Releases / 2001/03/Tropical-Disease-Research-and-Development (accessed on 16 March 2019). 
76. Bandyopadhyay, R.; Ortega-Beltran, A.; Akande, A.; Atehnkeng, J.; Kaptoge, L.; Adhikari, B.N.; Cotty, P.J. Biological control of aflatoxins in Africa: Current status and potential challenges in the face of climate change. World Mycotoxin J. 2016, 9, 771-789. [CrossRef]

77. Kaslow, D.C.; Black, A.S.; Bloom, D.E.; Datla, M.; Salisbury, D.; Rappuoli, R. Vaccine candidates for poor nations are going to waste. Nature 2018, 564, 337-339. [CrossRef] [PubMed]

78. GAVI. Ebola Vaccine to Help Tackle DRC Outbreak. Available online: https:/ /www.gavi.org/library/news / statements /2018/ebola-vaccine-to-help-tackle-drc-outbreak/ (accessed on 31 July 2018).

79. Madhi, S.A.; Levine, O.S.; Cherian, T. Pneumococcal conjugate vaccine is efficacious and effective in reducing the burden of pneumonia. Bull. World Health Organ. 2008, 86, A-C. [CrossRef]

80. Dabade, G.; Puliyel, J. Global health and the Bill \& Melinda Gates Foundation. Lancet 2009, 373, $2195-2196$. [PubMed]

81. Kelland, K. WHO's Strategic Advisory Group of Experts on Immunization Malaria Policy Advisory Committee called for the vaccine to be given on a pilot basis. Scientific American. Available online: https://www.scientificamerican.com/article/world-s-first-malaria-vaccine-delayed-as-who-ex perts-urge-caution/ (accessed on 17 March 2019).

82. Nayyar, G.M.L.; Breman, J.G.; Mackey, T.K.; Clark, J.P.; Hajjou, M.; Littrell, M.; Herrington, J.E. Falsified and substandard drugs: Stopping the pandemic. Am. J. Trop. Med. Hyg. 2019. [CrossRef]

83. Deaton, A. The logic of effective altruism. Boston Rev. 2015. Available online: http://bostonreview.net/for um/logic-effective-altruism/angus-deaton-response-effective-altruism (accessed on 16 March 2019).

84. McCoy, D.; Kembhavi, G.; Patel, J.; Luintel, A. The Bill \& Melinda Gates Foundation's grant-making programme for global health. Lancet 2009, 373, 1645-1653. [PubMed]

85. Kenny, K.E. The biopolitics of global health: Life and death in neoliberal time. J. Sociol. 2015, 51, 9-27. [CrossRef]

86. Reddy, S.G.; Pogge, T.W. How Not to Count the Poor!-A Reply to Ravallion. Available online: https: / / scholar.google.com.au/scholar?hl=en\&as_sdt=0\%2C5\&q=How+Not+to+Count+the+Poor\%21+ $\%$ E2\%80\%94+A+Reply+to+Ravallion\&btnG (accessed on 16 March 2019).

87. Tichenor, M.; Sridhar, D. Global health disruptors: The Bill and Melinda Gates Foundation. BMJ Blog 2018. Available online: https:/ /blogs.bmj.com/bmj/2018/11/28/global-health-disruptors-the-bill-and-melin da-gates-foundation/ (accessed on 16 March 2019).

88. Anonymous. Gates Foundation grants additional $\$ 6.4$ million to Cornell's controversial Alliance for Science. 2017. Available online: https://www.independentsciencenews.org/news/gates-foundation-grants-additi onal-6-4million-to-cornells-controversial-alliance-for-science/ (accessed on 31 July 2018).

89. George, S. The Lugano Report: On Preserving Capitalism in the Twenty-First Century; Pluto Press: London, UK, 1999; p. 213.

90. Gostin, L.O.; Friedman, E.A.A. Retrospective and prospective analysis of the West African Ebola virus disease epidemic: Robust national health systems at the foundation and an empowered WHO at the apex. Lancet 2015, 385, 1902-1909. [CrossRef]

91. Piller, C.; Sanders, E.; Dixon, R.; Writers, T.S. Dark cloud over good works of Gates Foundation. Los Angeles Times. 2007. Available online: http:/ / www.digitaljournal.com/article/87042 (accessed on 7 March 2019).

92. Carrington, D.; Mathiesen, K. Analysis of the Bill and Melinda Gates Foundation's most recent tax filing reveals huge investments in the world's biggest fossil fuel companies. 2015. Available online: https:/ / www.theguardian.com/environment/2015/mar/19/gates-foundation-has-14bn-in-fossi l-fuels-investments-guardian-analysis (accessed on 17 March 2019).

93. Barlow, P.; Serôdio, P.; Ruskin, G.; McKee, M.; Stuckler, D. Science organisations and Coca-Cola's 'war' with the public health community: Insights from an internal industry document. J. Epidemiol. Community Health 2018. [CrossRef] [PubMed]

94. Stuckler, D.; McKee, M.; Ebrahim, S.; Basu, S. Manufacturing epidemics: The role of global producers in increased consumption of unhealthy commodities including processed foods, alcohol, and tobacco. Public Libr. Sci. Med. 2012, 9, e1001235. [CrossRef] [PubMed]

95. Blackwell, R. Gates charity cuts funding to Canadian anti-smoking project in Africa. 2010. Available online: https:/ / www.theglobeandmail.com/news/world/gates-charity-cuts-funding-to-canadian-anti-s moking-project-in-africa/article1373518/ (accessed on 22 March 2019).

96. Piller, C. At arm's length. Science 2018, 362, 1100-1103. [CrossRef] 
97. Butler, C.D. Environmental change, injustice and sustainability. J. Bioeth. Inq. 2008, 5, 11-19. [CrossRef]

98. Motlagh, J.; Saha, A. The Ghosts of Rana Plaza: In Bangladesh, one year after the worst accident in the history of the garment industry, recovery remains a fragile process, justice seems elusive, and reform has a long way to go. Va. Quart. Rev. 2014, 90, 44-89.

99. Pun, N.; Shen, Y.; Guo, Y.; Lu, H.; Chan, J.; Selden, M. Apple, Foxconn, and Chinese workers' struggles from a global labor perspective. Inter-Asia Cult. Stud. 2016, 17, 166-185. [CrossRef]

100. Giridharadas, A. Winners Take All: The Elite Charade of Changing the World; Alfred A. Knopf: New York, NY, USA, 2018; p. 304.

101. Wright, J. Bill Gates shows his true colours after a journalist finally raises the problem with his charity work. The Canary. 2019. Available online: https://www.thecanary.co/trending/2019/01/23/bill-gatesshows-his-true-colours-after-a-journalist-finally-raises-the-problem-with-his-charity-work/ (accessed on 17 March 2019).

102. Stiglitz, J.E. The Price of Inequality; W. W. Norton \& Company: New York, NY, USA, 2012; p. 414.

103. Wu, T. The Curse of Bigness: Antitrust in the New Gilded Age; Columbia Global Reports: New York, NY, USA, 2018; p. 170.

104. Carrington, D. Bill and Melinda Gates Foundation divests entire holding in BP. The Guardian. 2016. Available online: https: / www.theguardian.com/environment/2016/may/12/bill-and-melinda-gates-foundationdivests-entire-holding-in-bp (accessed on 17 March 2019).

105. Hitchens, C. The Missionary Position. Mother Teresa in Theory and Practice; Verso: London, UK, 1995; p. 128.

106. Maguire, K. University accepts tobacco 'blood money'. The Guardian. 2000. Available online: https: / / www.theguardian.com/uk/2000/dec/05/highereducation.education (accessed on 17 March 2019).

107. MacAskill, W. Does divestment work? The New Yorker. 2015. Available online: https://www.newyorker.co $\mathrm{m} /$ business / currency / does-divestment-work (accessed on 17 March 2019).

108. Carrington, D. Wellcome Trust defies campaigners to increase fossil fuel investment. The Guardian. 2015. Available online: https://www.theguardian.com/environment/2015/dec/28/wellcome-trust-defies-ca mpaigners-to-increase-investment-in-fossil-fuels (accessed on 17 March 2019).

109. Horton, R.; Lo, S. Planetary health: A new science for exceptional action. Lancet 2015, 386, $1921-1922$. [CrossRef]

110. Rockefeller, D., Jr. The role of foundations: Rockefeller Foundation. Public Health Rev. 2016, 37, 32. [CrossRef] [PubMed]

111. Anonymous. Global Consortium formed to educate leaders on climate and health. 2017. Available online: https: / / www.mailman.columbia.edu/public-health-now / news / global-consortium-formed-edu cate-leaders-climate-and-health (accessed on 17 March 2019).

112. Rockefeller Brothers Fund. Divestment Statement. 2014. Available online: https://www.rbf.org/about/dive stment (accessed on 17 March 2019).

113. Reverby, S.M. "Normal exposure" and inoculation syphilis: A PHS "Tuskegee" doctor in Guatemala, 1946-1948. J. Policy Hist. 2011, 23, 6-28. [CrossRef]

114. Voss, S. We need an energy miracle. The Atlantic. 2016. Available online: http://www.theatlantic.com/maga zine/archive/2015/11/we-need-an-energy-miracle/407881/ (accessed on 17 March 2019).

115. Treuer, G.A. The psychology of Miami's struggle to adapt to sea-level rise. Bull. Atomic Sci. 2018, 74, $155-159$. [CrossRef]

116. Cai, W.; Santoso, A.; Wang, G.; Yeh, S.-W.; An, S.-I.; Cobb, K.M.; Collins, M.; Guilyardi, E.; Jin, F.-F.; Kug, J.-S.; et al. ENSO and greenhouse warming. Nat. Clim. Chang. 2015, 5, 849-859. [CrossRef]

117. Perry, S.J.; McGregor, S.; Gupta, A.S.; England, M.H. Future changes to El Niño-Southern Oscillation temperature and precipitation teleconnections. Geophys. Res. Lett. 2017, 44, 10608-10616. [CrossRef]

118. Howard, E. Bill Gates calls fossil fuel divestment a 'false solution'. The Guardian. 2015. Available online: https:/ / www.theguardian.com/environment/2015/oct/14/bill-gates-calls-fossil-fuel-divestmen t-a-false-solution (accessed on 17 March 2019).

119. Shah, J. Sorry Bill Gates, you are wrong on renewable energy. 2014. Available online: http://www.greentec hmedia.com/articles/read/sorry-bill-gates-you-are-wrong-on-clean-energy (accessed on 17 March 2019).

120. Dattaro, L. Tech Titans Like Bill Gates Are Gambling on Nuclear Power-But It Looks to Be a Losing Bet. 2015. Available online: https://news.vice.com/article/tech-titans-like-bill-gates-are-gambling-on-nuclea r-power-but-it-looks-to-be-a-losing-bet (accessed on 17 March 2019). 
121. Kromdijk, J.; Głowacka, K.; Leonelli, L.; Gabilly, S.T.; Iwai, M.; Niyogi, K.K.; Long, S.P. Improving photosynthesis and crop productivity by accelerating recovery from photoprotection. Science 2016, 354, 857-861. [CrossRef] [PubMed]

122. Loladze, I. Hidden shift of the ionome of plants exposed to elevated $\mathrm{CO}_{2}$ depletes minerals at the base of human nutrition. eLIFE 2014, 3, e02245. [CrossRef] [PubMed]

123. Steffen, W.; Rockström, J.; Richardson, K.; Lenton, T.M.; Folke, C.; Liverman, D.; Summerhayes, C.P.; Barnosky, A.D.; Cornell, S.E.; Crucifixi, M.; et al. Trajectories of the Earth System in the Anthropocene. Proc. Natl. Acad. Sci. USA 2018, 115, 8252-8259. [CrossRef] [PubMed]

124. Bloom, P.; Rhodes, C. CEO Society: The Corporate Takeover of Everyday Life; University of Chicago Press: Chicago, IL, USA, 2018; p. 224.

125. Butler, C.D. Sounding the alarm: Health in the Anthropocene. Int. J. Environ. Res. Public Health 2016, 13, 665. [CrossRef] [PubMed]

126. Walls, H.L.; Butler, C.D.; Dixon, J.; Samarawickrema, I.; the Society, Culture and Health Group. Implications of 'structure versus agency' for addressing health and well-being in our ecologically-constrained world. Int. J. Fem. Approaches Bioeth. 2015, 8, 47-69.

(C) 2019 by the author. Licensee MDPI, Basel, Switzerland. This article is an open access article distributed under the terms and conditions of the Creative Commons Attribution (CC BY) license (http://creativecommons.org/licenses/by/4.0/). 